\title{
Pengaruh Terapi Vitamin D Terhadap Kadar Kalsidiol dan CD4 pada Anak dengan Human Immunodeficiency Virus Dalam Terapi Antiretroviral
}

Reza Chandra Abdilla, Rustam Siregar, Fadhilah Tia Nur

Bagian Ilmu Kesehatan Anak Fakultas Kedokteran Universitas Sebelas Maret/RSUD Dr. Moewardi, Surakarta

Latar belakang. Publikasi ilmiah terdahulu telah membuktikan bagaimana vitamin D berdampak terhadap imunitas pasien HIV. Kadar vitamin D yang adekuat berkaitan erat dengan luaran klinis dan kadar CD4 yang lebih baik. Hingga kini belum terdapat penelitian yang mengkaji pengaruh terapi vitamin D pada anak HIV dalam terapi antiretroviral di Indonesia.

Tujuan. Untuk menganalisis pengaruh terapi vitamin D terhadap kadar kalsidiol dan CD4 pada pasien HIV dalam terapi antiretroviral.

Metode. Penelitian ini bersifat pra-eksperimental dengan pretest-posttest design. Kriteria inklusi subjek penelitian adalah pasien HIV dalam terapi antiretroviral lini pertama, berada dalam stadium klinis HIV satu atau dua, berusia kurang dari 18 tahun. Penelitian dilaksanakan di Rumah Sakit dr. Moewardi, Surakarta pada periode waktu Maret - September 2020. Kadar kalsidiol dan CD4 diperiksa sebelum dan sesudah intervensi pemberian vitamin D. Pasien dengan kadar insufisiensi atau defisiensi vitamin D diberikan vitamin D3 2000 IU/hari selama 24 minggu. Uji analisis multivariat dilakukan dengan t-test berpasangan, dimana nilai $\mathrm{p}<0,05$ dianggap signifikan.

Hasil. Didapatkan peningkatan yang signifikan pada kadar kalsidiol pasien sebelum dan sesudah intervensi yaitu 18,29ng/ml $\pm 5,37 \mathrm{dan}$ $32,34 \mathrm{ng} / \mathrm{ml} \pm 6,78$, juga didapatkan peningkatan kadar CD4 dari 860.74/mm3 $\pm 396,09$ dan 1020.26/mm3 $\pm 520,63$ secara berurutan.

Kesimpulan. Terdapat peningkatan yang signifikan terhadap kadar kalsidiol dan CD4 pada pasien HIV dalam terapi antiretroviral setelah terapi vitamin D. Sari Pediatri 2021;23(3):143-9

Kata kunci: antiretroviral, CD4, HIV, kalsidiol, vitamin D

\section{Effect of Vitamin D Therapy on Calcidiol and CD4 Levels in Children with Human Immunodeficiency Virus Under Antiretroviral Therapy}

Reza Chandra Abdilla, Rustam Siregar, Fadhilah Tia Nur

Background. Previous scientific publications have proven how vitamin D affects the immunity of HIV patients. Adequate vitamin D levels are closely associated with better clinical outcomes and CD4 levels. Until nowadays there has been no research discussing the effect of vitamin $\mathrm{D}$ therapy in HIV children under antiretroviral therapy in Indonesia.

Objective. This study aimed to analyze the effect of vitamin D therapy on calcidiol and CD4 levels in HIV patients under antiretroviral therapy. Methods. This research is pre-experimental with a pretest-posttest design. The inclusion criteria for study subjects were HIV patients under first-line antiretroviral therapy, belong to HIV clinical stage one or two, aged less than 18 years. This research was conducted at dr. Moewardi hospiral, Surakarta in the period March - September 2020. Levels of calcidiol and C4 were measured before and after the intervention of vitamin D therapy. Patients with vitamin D insufficiency or deficiency were given 2000 IU / day of vitamin D3 for 24 weeks. The multivariate analysis test was carried out with paired t-test, with $p$ value $<0.05$ considered as significant.

Results. Calcidiol level was significantly increased in patients before and after intervention that is $18.29 \mathrm{ng} / \mathrm{ml}+5.37 \mathrm{and} 32.34 \mathrm{ng} / \mathrm{ml}+6.78$, also an increase in CD4 levels from $860.74 / \mathrm{mm} 3+396.09$ to $1020.26 / \mathrm{mm} 3+520.63$ respectively.

Conclusion. There was a significant increase in calcidiol and CD4 levels in HIV patients under antiretroviral therapy after vitamin D therapy. Sari Pediatri 2021;23(3):143-9

Key words: antiretroviral, calcidiol, CD4, HIV, vitamin D

Alamat korespondensi: dr. H. Rustam Siregar, SpA. Departemen Ilmu Kesehatan Anak Fakultas Kedokteran UNS/ RSUD Dr. Moewardi Gedung Anggrek Lantai 4, Jl. Kolonel Soetarto No. 132, Surakarta 57126. Email: ppdsika@gmail.com 
S ejak kasus pertama infeksi human immunodeficiency virus (HIV) diidentifikasi, jumlah anak yang terinfeksi di negara berkembang telah meningkat akibat peningkatan jumlah perempuan usia subur yang terinfeksi HIV. Infeksi HIV vertikal terjadi sebelum kelahiran, selama persalinan, atau setelah kelahiran. ${ }^{1}$ Dalam sebuah penelitian terhadap anak yang terinfeksi HIV-1, highly active antiretroviral therapy (HAART) menunjukkan bahwa inisiasi terapi antiretroviral pada usia yang lebih muda dan kadar CD4 yang lebih sehat menghasilkan pemulihan kekebalan yang lebih baik. ${ }^{2,3}$

Secara keseluruhan, $72 \%$ anak yang mengalami status imunosupresi pada awal pengobatan, kadar CD4 dapat pulih normal dalam waktu 4 tahun setelah mulai terapi antiretroviral. Dibandingkan dengan anak dengan imunosupresi berat, lebih banyak anak dengan imunosupresi ringan $(+36 \%)$ atau imunosupresi sedang $(+20,8 \%)$ yang mendapatkan pemulihan kadar normal CD4. Untuk setiap peningkatan 5 tahun pada usia awal terapi, proporsi anak yang mencapai persentase normal kadar CD4 menurun 19\%. ${ }^{3}$

Studi terbaru menunjukkan bahwa terapi antiretroviral mungkin memiliki efek pada vitamin D, hormon paratiroid $(\mathrm{PTH})$, remodeling tulang, bone mineral density (BMD) dan risiko mengembangkan fraktur. ${ }^{4}$ Vitamin D yang inadekuat (didefinisikan sebagai level serum $25(\mathrm{OH})$ vitamin $\mathrm{D}<32 \mathrm{ng} / \mathrm{ml})$ tersebar luas di antara orang yang terinfeksi HIV, dengan perkiraan prevalensi mulai dari 29 hingga 89 persen pada populasi yang terinfeksi HIV di Eropa dan Amerika Serikat. ${ }^{5}$ Oleh sebab itu, pengukuran 25-hidroksi vitamin D [kalsidiol, $25(\mathrm{OH}) \mathrm{D}$ ] dan penggantian suplementasi vitamin $\mathrm{D}$, pada mereka dengan kadar rendah, telah banyak diadopsi dalam praktik klinis pengobatan HIV. Namun, bukti untuk manfaat klinis atau efektivitas biaya masih kurang. ${ }^{6}$

Obat antiretroviral spesifik termasuk efavirenz dan zidovudine, telah dikaitkan dengan kadar vitamin D serum yang lebih rendah dan mungkin memperburuk masalah ini. ${ }^{7}$ Terdapat banyak bukti menunjukkan bahwa vitamin $\mathrm{D}$ mengurangi proses imunitas karena regulasi mediator anti inflamasi meningkat. Vitamin D menginduksi perubahan regulasi respon imun Th1 dan proliferasi dari sel B yang teraktivasi serta meningkatkan regulasi Treg. Sejalan dengan hal ini, beberapa penelitian terbaru mengidentifikasi kemungkinan hubungan antara peningkatan kadar vitamin D dengan kadar CD4 pada penyakit HIV, tetapi belum terdapat penelitian yang menghubungkan kadar vitamin D dan kadar CD4 pada anak HIV dalam terapi ARV di Indonesia. ${ }^{6}$

Endocrine society di Amerika Serikat pada tahun 2011 merekomendasikan pembatasan skrining hanya untuk orang yang berisiko kekurangan vitamin $\mathrm{D}$ dan merekomendasikan suplementasi vitamin D (15002000 IU / hari) untuk mencapai kadar lebih dari 30 ng / ml. ${ }^{8}$ Penelitian ini bertujuan untuk menganalisis pengaruh terapi vitamin $\mathrm{D}$, profil kalsidiol dan CD4 pada penderita HIV dalam terapi antiretroviral sebelum dan sesudah pemberian terapi vitamin $\mathrm{D}$.

\section{Metode}

Penelitian ini bersifat pra-eksperimental dengan pretest-posttest design (rancangan uji sebelum-sesudah). ${ }^{9}$ Pengambilan sampel dilakukan secara consecutive sampling. Semua subyek yang datang dan memenuhi kriteria inklusi dimasukkan dalam penelitian sampai jumlah subyek terpenuhi. Subyek meliputi anak dengan penyakit dasar HIV yang mendapat terapi antiretroviral (Zidovudine dan atau Efavirenz) dengan defisiensi dan atau insufisiensi vitamin D di Poliklinik Departemen Ilmu Kesehatan Anak RSUD Dr. Moewardi, mulai Maret - September 2020. Kriteria inklusi adalah pasien HIV dalam terapi antiretroviral lini pertama (Zidovudine dan atau Efavirenz) yang berusia kurang dari 18 tahun, terdaftar sebagai pasien yang periksa di RSUD Dr. Moewardi Surakarta, dan bersedia mengikuti penelitian dengan menandatangani persetujuan informed consent. Subjek penelitian menjalani pemeriksaan laboratorium darah berupa kadar vitamin $\mathrm{D}$ yang diperiksa dalam bentuk kalsidiol dan kadar CD4. Selanjutnya, pada pasien dengan insufisiensi dan atau defisiensi vitamin D diberikan terapi vitamin $\mathrm{D}_{3} 2000 \mathrm{IU} /$ hari (Puritan ${ }^{\odot}$ ) selama 24 mingggu, kemudian dilakukan pengukuran ulang laboratorium darah, kadar kalsidiol dan kadar CD4 setelahnya. Kriteria eksklusi adalah pasien HIV dalam terapi antiretroviral dengan stadium klinis tiga dan empat dengan komorbiditas penyakit lain, perubahan terapi antiretroviral dalam kurun waktu enam bulan terakhir, dan pasien yang mendapat suplementasi / terapi vitamin D sebelumnya, kadar kalsidiol sufisiensi sebelum intervensi. Penelitian ini telah memperoleh kelaikan etik dari Medical and Health Research Ethics Committee (MHREC) RSUD Dr. Moewardi/ Fakultas Kedokteran Universitas Sebelas Maret, Surakarta. 
Dilakukan analisis data pada karakteristik subyek penelitian yang meliputi umur, jenis kelamin, status gizi, regimen terapi antiretroviral, lama terapi, stadium klinis HIV, dan kadar kalsidiol. Adapun variabel perancu seperti kepatuhan minum obat, asupan diet vitamin D harian, lama paparan sinar matahari, data diperoleh dari kuesioner yang akan dianalisis melalui program nutrisurvey 2007. Kadar kalsidol yang diperiksa dikategorikan menjadi insufisiensi bila berada pada 20-30 ng/ml, dan defisiensi bila di bawah $20 \mathrm{ng} / \mathrm{ml}$, dan diperiksa dengan alat terstandar kromatografi dengan spektrometri (Liaison ${ }^{\circledR}$ ). Kadar CD4 dinilai dengan nilai absolute $\left(\mathrm{sel} / \mathrm{mm}^{3}\right)$ yang diperiksa dengan alat flowsitometri (BD FACSCanto ${ }^{\mathrm{TM}}$ ).

Data yang diambil tersebut dimasukkan ke dalam program perangkat lunak SPSS ${ }^{\circ} 22$. Data dianalisis menggunakan uji $\mathrm{T}$ berpasangan jika data terdistribusi normal dan menggunakan uji Wilcoxon jika tidak terdistribusi normal. Bila pada uji $\mathrm{T}$ berpasangan atau Wilcoxon diperoleh hasil yang signifikan, dilakukan analisis uji korelasi post-hoc. Analisis posthoc untuk karakteristik subyek dengan uji korelasi eta karena mengorelasikan antara data kategorik dan numerik, kecuali untuk asupan diet vitamin D harian menggunakan uji spearman rank, karena data numeriknumerik tidak terdistribusi normal Tingkat kemaknaan dalam penelitian ini dinyatakan bila $\mathrm{p}<0,05$.

\section{Hasil}

Subyek penelitian didapatkan 23 pasien anak dari 26 pasien dengan penyakit dasar HIV dalam terapi antiretroviral yang memenuhi kriteria inklusi. Pada penelitian ini terdapat 3 pasien yang masuk dalam kriteria eksklusi dengan kadar kalsidiol normal sebelum intervensi, dan satu pasien yang meninggal saat periode intervensi sebelum dilakukan pemeriksaan darah setelah terapi vitamin $\mathrm{D}$.

Karakteristik subyek dari penelitian ini disajikan dalam bentuk proporsi (\%), mean dan median (IQR) yang tertera pada Tabel 1.

Dari tabel di atas rerata usia pasien adalah 10,43 $\pm 3,73$ tahun dengan sebagian besar dengan usia $>10$ tahun, yaitu $12(52,2 \%)$ pasien. Jenis kelamin sebagian besar perempuan, yaitu $13(56,5 \%)$ pasien. Status gizi secara antropometris mayoritas berada dalam kategori gizi baik, yaitu 14 (60,9\%) pasien. Regimen
Tabel 1. Karakteristik subyek penelitian $(\mathrm{n}=23)$

\begin{tabular}{|c|c|}
\hline Karakteristik & $\%$ \\
\hline Umur (tahun) & $10,43 \pm 3,73$ \\
\hline$<10$ & $11(47,8)$ \\
\hline$>10$ & $12(52,2)$ \\
\hline \multicolumn{2}{|l|}{ Jenis kelamin } \\
\hline Perempuan & $13(56,5)$ \\
\hline Laki-laki & $10(43,5)$ \\
\hline \multicolumn{2}{|l|}{ Status gizi (antropometris) } \\
\hline Kurang & $6(26,1)$ \\
\hline Baik & $14(60,9)$ \\
\hline Lebih & $2(8,7)$ \\
\hline Obese & $1(4,3)$ \\
\hline \multicolumn{2}{|l|}{ Regimen ARV } \\
\hline 3TC, TDF, EFV & $3(13,0)$ \\
\hline AZT, 3TC, EFV & $4(17,4)$ \\
\hline AZT, 3TC, NEV & $16(69,6)$ \\
\hline \multicolumn{2}{|l|}{ Lama terapi (bulan) } \\
\hline $6-12$ & $1(4,3)$ \\
\hline $12-18$ & $1(4,3)$ \\
\hline$>18$ & $21(91,3)$ \\
\hline Perancu asupan vitamin D (IU/ hari) & $146,74 \pm 65,84$ \\
\hline \multicolumn{2}{|l|}{ Paparan sinar matahari (menit) } \\
\hline$<30$ & $4(17,4)$ \\
\hline $30-60$ & $19(82,6)$ \\
\hline \multicolumn{2}{|l|}{ Stadium klinis HIV } \\
\hline I & $21(91,3)$ \\
\hline II & $2(8,7)$ \\
\hline \multicolumn{2}{|l|}{ Kadar kalsidiol } \\
\hline Defisiensi & $14(60,9)$ \\
\hline Insufusiensi & $9(39,1)$ \\
\hline
\end{tabular}

Keterangan : Lamivudine (3TC), Tenofovir (TDF), Efavirenz (EFV), Zidovudine (AZT), Nevirapine (NEV)

antiretroviral yang digunakan sebagian besar adalah AZT, 3TC, NEV, yaitu $16(69,6 \%)$ pasien. Lama terapi sebagian besar $>18$ bulan, yaitu $21(91,3 \%)$ pasien. Asupan vitamin D rerata sebesar 146,74_65,84 IU/ hari. Lama paparan sinar matahari sebagian besar 30-60 menit, yaitu $19(82,6 \%)$ pasien. Stadium klinis HIV sebagian besar dalam kategori stage I, yaitu 21 (91,3\%) pasien dan kadar kalsidiol sebagian besar dalam kategori defisiensi, yaitu $14(60,9 \%)$ pasien.

Sebelum intervensi pemberian terapi vitamin D pada awal penelitian dilakukan, rerata kadar kalsidiol pasien berada pada tingkat defisiensi dengan rentang nilai $18,29 \pm 5,37 \mathrm{ng} / \mathrm{ml}$. Setelah terapi vitamin D 
Reza Chandra Abdilla dkk: Pengaruh terapi vitamin D terhadap kadar kalsidiol dan CD4 pada HIV dalam terapi antiretroviral

Tabel 2. Pengaruh terapi vitamin D terhadap kadar kalsidiol dan CD4

\begin{tabular}{lcccc}
\hline Variabel & Pre & Post & Diff Mean (IK95\% ) & p \\
\hline Kalsidiol & $18,29 \pm 5,37$ & $32,34 \pm 6,78$ & $14,05(11,88 \mathrm{~s} / \mathrm{d} \mathrm{16.22)}$ & $<0,001^{*}$ \\
CD4 & $860,74 \pm 396,09$ & $1020,26 \pm 520,63$ & $159,52(10,44 \mathrm{~s} / \mathrm{d} \mathrm{308,60)}$ & $0,037^{*}$ \\
\hline
\end{tabular}

Keterangan : *Uji t test berpasangan

diberikan selama 24 minggu, rerata kadar kalsidiol berkisar pada rentang $32,34 \pm 6,78 \mathrm{ng} / \mathrm{ml}$. Interval kepercayaan rata-rata sebesar 14.05 (IK95\%= 11,88 - 16,22) dengan $\mathrm{p}<0,001$. Sebelum terapi vitamin D rerata CD4 860,74 $\pm 396,09 \mathrm{sel} / \mathrm{mm}^{3}$, kemudian rentang setelah terapi vitamin $\mathrm{D}$ selama 24 minggu $1020,26 \pm 520,63 \mathrm{sel} / \mathrm{mm}^{3}$. Interval kepercayaan ratarata $159,52(\mathrm{IK} 95 \%=10,44-308,60)$ dengan $\mathrm{p}=0,037$.

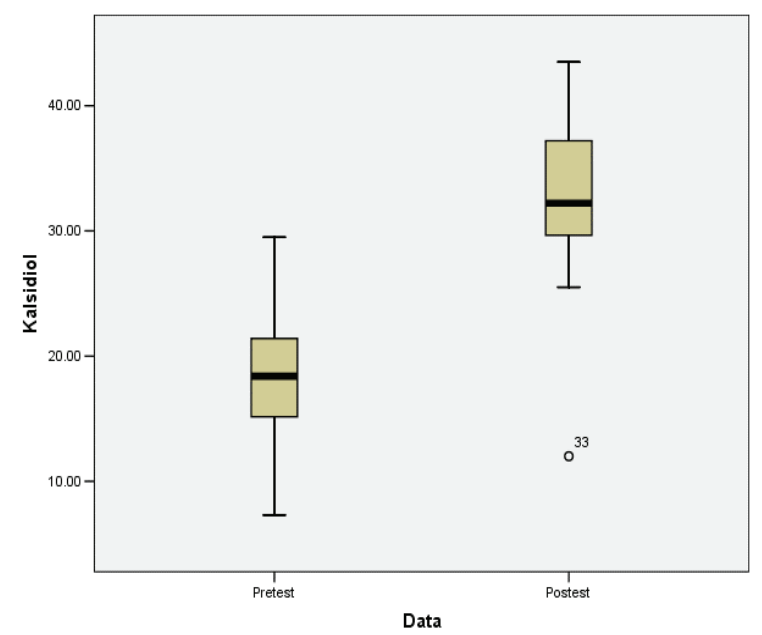

Gambar 1. kadar kalsidiol pretest (a) dan postest (b) terapi vitamin $\mathrm{D}$

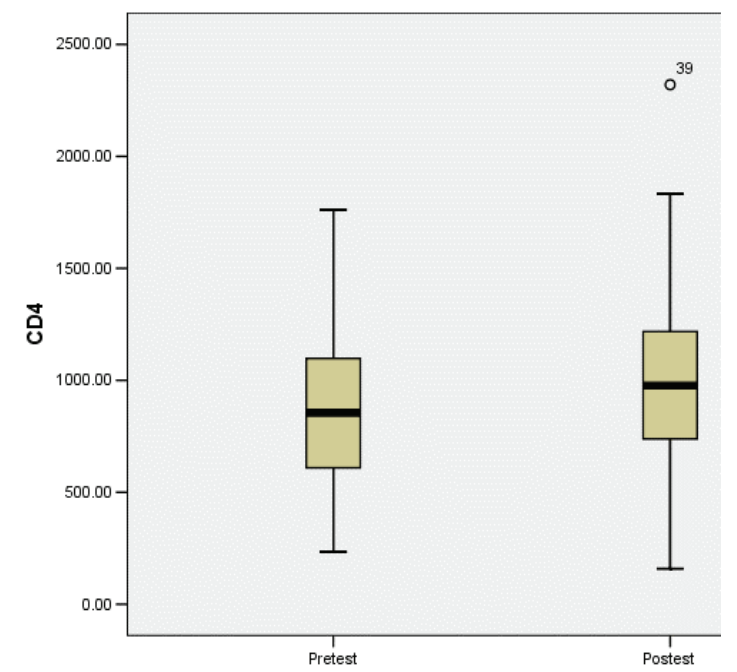

Gambar 2. Box plot kadar CD4 pretest (a) dan postest (b) terapi vitamin $\mathrm{D}$
Hasil uji korelasi karakteristik subyek penelitian terhadap kadar kalsidiol dan CD4 ditampilkan pada tabel berikut

Berdasarkan tabel diatas, diketahui bahwa umur $(\mathrm{p}=0,941)$, jenis kelamin $(\mathrm{p}=0,803)$, regimen antiretroviral $(\mathrm{p}=0,086)$, lama terapi $(\mathrm{p}=0,694)$, asupan vitamin $\mathrm{D}(\mathrm{p}=0,722)$, paparan sinar matahari $(\mathrm{p}=0,975)$, dan stadium klinis HIV $(\mathrm{p}=0,211)$ tidak memiliki hubungan yang signifikan terhadap peningkatan kalsidiol. Pada selisih peningkatan CD4 diketahui bahwa umur $(\mathrm{p}=0,059)$, jenis kelamin $(\mathrm{p}=0,272)$, regimen antiretroviral $(\mathrm{p}=0,606)$, lama terapi $(\mathrm{p}=0,892)$, asupan vitamin $D(p=0,190)$, dan stadium klinis HIV ( $\mathrm{p}=0,130)$ juga tidak memiliki hubungan yang signifikan terhadap peningkatan CD4.

Lama paparan sinar matahari sebagai variabel perancu, secara statistik mendapatkan hasil yang signifikan terhadap peningkatan CD 4 pre-post terapi vitamin $\mathrm{D}$ dengan nilai $(\mathrm{r}=0,434 ; \mathrm{p}=0,038)$. Pasien dengan lama paparan sinar matahari $<30$ menit cederung mengalami penurunan nilai CD4 sebesar $-159.50 \pm 186.55$, sedangkan pasien dengan lama paparan sinar matahari 30-60 menit cederung mengalami peningkatan nilai CD4 sebesar 226.68 \pm 334.79 . Pada analisis data di atas, lama paparan sinar matahari selama 30-60 menit memiliki korelasi positif yang lemah, tetapi secara statistik signifikan dengan peningkatan kadar CD4.

\section{Pembahasan}

Rerata kadar kalsidiol pasien di awal penelitian adalah $18,29 \pm 5,37 \mathrm{ng} / \mathrm{ml}$ sehingga semua pasien masuk dalam kelompok defisiensi vitamin D. Oleh karena itu, pasien mendapatkan terapi vitamin D 2000 IU/hari selama 24 minggu. Setelah dilakukan terapi vitamin D, kadar kalsidiol pasien meningkat secara signifikan dengan rerata 32,34 $\pm 6,78$ dengan rentang interval kepercayaan $95 \%$ yang cukup sempit. Hal ini menandakan bahwa ketika sample tersebut dibawa ke populasi umum akan memberikan hasil yang cukup homogen dan presisi. 
Reza Chandra Abdilla dkk: Pengaruh terapi vitamin D terhadap kadar kalsidiol dan CD4 pada HIV dalam terapi antiretroviral

Tabel 3. Hubungan karakteristik subyek terhadap kadar kalsidiol dan CD4

\begin{tabular}{|c|c|c|c|c|c|}
\hline Karakteristik & $\mathrm{N}$ & $\begin{array}{l}\text { Peningkatan Kalsidiol pre- } \\
\text { post terapi vitamin D }\end{array}$ & $\mathrm{p}$ & $\begin{array}{c}\text { Peningkatan CD } 4 \\
\text { pre-post terapi vitamin D }\end{array}$ & $\mathrm{p}$ \\
\hline Umur $^{\mathrm{a}}$ (tahun) & & & 0,941 & & 0,059 \\
\hline$<10$ & 11 & $14,14 \pm 4,80$ & $\mathrm{r}=0.016$ & $300,27 \pm 400,17$ & $\mathrm{r}=0,400$ \\
\hline$>10$ & 12 & $13,98 \pm 5,41$ & & $30,50 \pm 232,70$ & \\
\hline Jenis kelamin ${ }^{a}$ & & & 0,803 & & 0,272 \\
\hline Perempuan & 13 & $13,82 \pm 5,38$ & $r=0,055$ & $230,15 \pm 413,69$ & $r=0,239$ \\
\hline Laki-laki & 10 & $14,36 \pm 4,76$ & & $67,70 \pm 213,92$ & \\
\hline Status gizi (antropometris) $)^{\mathrm{a}}$ & & & 0,758 & & 0,964 \\
\hline Kurang & 6 & $14,73+5,26$ & $r=0,242$ & $214,33+352,74$ & $\mathrm{r}=0,119$ \\
\hline Normal & 14 & $13,64+5,32$ & & $132,14+387,53$ & \\
\hline Lebih & 2 & $12,50+3,82$ & & $212,50+58,69$ & \\
\hline Obes & 1 & $18,80+-$ & & $108,00+-$ & \\
\hline Regimen antiretroviral $^{a}$ & & & 0,086 & & 0,606 \\
\hline 3TC, TDF, EFV & 3 & $8,47+1,53$ & $\mathrm{r}=0,466$ & $278,33+232,46$ & $\mathrm{r}=0,221$ \\
\hline AZT, 3TC, EFV & 4 & $16,48+4,33$ & & $16,00+117,46$ & \\
\hline AZT, 3TC, NEV & 16 & $14,49+4,98$ & & $173,13+394,76$ & \\
\hline Lama terapi ${ }^{\mathrm{a}}$ (bulan) & & & 0,694 & & 0,892 \\
\hline $6-12$ & 1 & $12,40+-$ & $r=0,189$ & 180.00 & $\mathrm{r}=0,107$ \\
\hline $12-18$ & 1 & $10,10+-$ & & 326,00 & \\
\hline$>18$ & 21 & $14,32+5,16$ & & $150,62+359,51$ & \\
\hline Asupan vitamin $\mathrm{D}^{\mathrm{b}}$ & 23 & $14,05+5,01$ & $\begin{array}{c}0,722 \\
\mathrm{r}=0,079\end{array}$ & $159,52+344,75$ & $\begin{array}{c}0.190 \\
\mathrm{r}=0,284\end{array}$ \\
\hline Paparan sinar mataharia & & & 0.975 & & $0,038^{*}$ \\
\hline$<30$ menit & 4 & $14,13+7,33$ & $\mathrm{r}=0,007$ & $-159.50+186.55$ & $r=0,434$ \\
\hline 30-60 menit & 19 & $14,04+4,67$ & & $226,68+334,79$ & \\
\hline Stadium klinis HIV & & & 0,211 & & 0,130 \\
\hline I & 21 & $14,46+5,06$ & $\mathrm{r}=0,271$ & $125,67+336,63$ & $\mathrm{r}=0,325$ \\
\hline II & 2 & $9,75+0,49$ & & $515,00+267,29$ & \\
\hline
\end{tabular}

Keterangan : ${ }^{\mathrm{a}} \mathrm{Uji}$ Eta; ${ }^{\mathrm{b}} \mathrm{Uji}$ Spearman rank

Hal ini berkesesuaian dengan penelitian terhadap pasien anak dengan HIV di Toronto, Kanada, pada tahun 2011 dan di Philadelphia, Amerika Serikat pada tahun 2015. Dalam penelitian tersebut terjadi penurunan kadar kalsidiol pada tahap insufisiensi hingga defisiensi pada $85 \%$ dan $90 \%$ dari total pasien secara berurutan. ${ }^{10,11}$

Penurunan kadar kalsidiol sebagai prekursor vitamin D pada pasien HIV dapat dikarenakan dari efek pemberian obat antiretroviral, seperti efavirenz pada kelas non-nucleoside reverse transcriptase inhibitor (NNRTI). Supresi enzim sitokrom P450 (CYP) 2R1 mengakibatkan homeostasis vitamin $\mathrm{D}$ terganggu.,
Enzim tersebut merupakan salah satu enzim yang terlibat dalam 25-hidroksilasi vitamin D3 dan vitamin D2 hingga terbentuknya kalsidiol. ${ }^{12}$ Selain itu, efavirenz telah terbukti menginduksi CYP24 yang mengubah kalsidiol dan kalsitriol menjadi bentuk metabolit yang tidak aktif. Adapun regimen antiretroviral utama lain, seperti zidovudine pada kelas nucleoside reverse transcriptase inhibitor (NRTI) ditengarai memberi andil dalam supresi enzim sitokrom P450 melalui peningkatan kadar laktat yang terakumulasi di liver. ${ }^{13}$ Penyebab lain bisa dimungkinkan karena pigmen kulit yang lebih gelap, gangguan hati, insufisiensi ginjal, 
penggunaan tabir surya, dan jumlah asupan vitamin $D$ yang terbatas dari sumber makanan. ${ }^{14}$

Penelitian di Jepang pada tahun 2000 dengan subyek dewasa membandingkan kadar vitamin D terhadap albumin serum juga didapatkan korelasi positif. Sebagian besar 25- $(\mathrm{OH})$ D3 dan 1,25- $(\mathrm{OH}) 2$ D3 terikat dan diangkut dalam plasma oleh protein pengikat vitamin $\mathrm{D}$ ( $D$ - binding protein/DBP). Dengan demikian, konsentrasi DBP serum yang menurun terbukti menyebabkan penurunan konsentrasi serum 1,25$(\mathrm{OH}) 2$ D3. Konsentrasi kadar DBP dan 1,25- $(\mathrm{OH}) 2$ D3 pada serum secara signifikan berkorelasi dengan konsentrasi albumin serum, sedangkan konsentrasi serum 1,25-(OH)2 D3 bebas tidak berkorelasi. Dengan demikian, konsentrasi albumin serum yang rendah dapat menyebabkan konsentrasi 1,25- $(\mathrm{OH}) 2 \mathrm{D} 3$ serum yang lebih rendah. Pada penelitian kami, rerata status gizi pasien secara antropometris berada dalam kategori gizi baik, dengan nilai korelasi lemah dan tidak bermakna terhadap peningkatan kadar kalsidiol maupun CD4. Adapun kadar albumin tidak termasuk dalam variabel data yang dianalisis. Untuk itu penelitian lebih lanjut diperlukan untuk bisa mengalisis hubungan variabel tersebut di masa datang. ${ }^{15}$ Penelitian sebelumnya pada subyek dewasa yang membandingkan kadar serum kalsidiol yang terikat dengan protein pengikat vitamin $\mathrm{D}(D B P)$ dan serum kalsidiol bebas juga menunjukkan hal serupa. Ditemukan korelasi yang positif dan kuat antara kadar serum kalsidiol bebas dan kalkulasi kadar kalsidiol bebas yang dihitung berdasarkan albumin dan konsentrasi DBP pada 16 subjek normal dan 16 pasien dengan penyakit liver. Hasil ini menegaskan konsep bahwa meskipun DBP adalah pembawa protein utama kalsidiol dalam serum, albumin adalah pembawa sekunder terutama pada pasien dengan kadar protein pengikat vitamin D yang rendah. ${ }^{16}$

Pada penelitian kami, penurunan kadar kalsidiol pada pasien yang menggunakan antiretroviral berbasis efavirenz dan zidovudine didapatkan $78 \%$ dan $94 \%$. Pada pasien yang menggunakan antiretroviral kombinasi zidovudine dan efavirenz, didapatkan 100\% subyek mengalami penurunan kadar kalsidiol. Adapun faktor perancu, seperti rerata asupan vitamin $\mathrm{D}$ harian, dan lama paparan sinar matahari tidak memiliki dampak yang bermakna dan memiliki korelasi yang lemah terhadap peningkatan kadar kalsidiol.

Rerata kadar CD4 pasien di awal penelitian kami adalah $860,74 \mathrm{sel} / \mathrm{mm}^{3} \pm 396,09$ dengan mayoritas pasien berada pada HIV stadium klinis I. Dari kondisi ini peneliti bisa meminimalisasi faktor perancu yang memengaruhi kadar CD4, terutama infeksi. Setelah dilakukan terapi vitamin D 2000IU/hari selama 24 minggu, rerata kadar CD4 pasien meningkat $1020,26 \pm 520,63$ dengan rentang interval kepercayaan 95\% yang cukup lebar. Rentang nilai tersebut akan memberikan hasil yang cukup heterogen ketika sampel tersebut dibawa ke populasi umum.

Pada penelitian yang dilakukan sebelumnya, dampak pemberian terapi vitamin $\mathrm{D}$ terhadap kadar CD 4 tampak beragam. Kakalia dkk ${ }^{10}$ meneliti tentang pemberian terapi vitamin D sebanyak 1600IU/ hari pada pasien HIV. Hasil penelitian tersebut melaporkan bahwa peningkatan kadar CD4 tidak berdampak, baik secara persentasi maupun absolut. Namun, Coelho dkk ${ }^{17}$ yang meneliti pasien dengan pemberian vitamin $\mathrm{D}$ 50,000 IU sebanyak 2 kali seminggu selama 5 minggu, kemudian 8000 IU sebanyak 2 kali seminggu hingga total 24 minggu didapatkan peningkatan kadar CD4 sebesar 3,3 sel $/ \mathrm{mm}^{3}$ yang berkorelasi positif dengan peningkatan kadar kalsidiol sebanyak $1 \mathrm{ng} / \mathrm{ml}$.

Pengaruh peningkatan kadar CD4 pasca pemberian terapi vitamin $\mathrm{D}$ disinyalir merupakan bagian dari efek immunomodulator pada vitamin $\mathrm{D}$ itu sendiri, yaitu membantu aktivasi sel $\mathrm{B}$ dan $\mathrm{T}$, menstimulasi fungsi sel $\mathrm{T}$, differensiasi serta proliferasi sel beta, memicu perkembangan dari $\mathrm{T}$ helper 2 melalui produksi IL4, IL5, IL10. Penelitian lain telah menunjukkan bahwa ekspresi epidermal vitamin D menghubungkan lingkungan ke sistem kekebalan melalui perluasan sel T regulatori CD4+ dan CD25+. ${ }^{18}$

Hasil analisis kami perihal hubungan karakteristik subyek dengan peningkatan kadar CD4 terdapat hal yang menarik, yakni durasi paparan sinar matahari selama ratarata 30-60 menit/hari memiliki dampak yang bermakna dan positif dengan peningkatan kadar CD4. Durasi paparan sinar matahari selama rata-rata $<30$ menit/hari akan terjadi penurunan kadar CD4 $(-159,50 \pm 186,55)$ dari nilai acuan awal CD4 sebelum terapi vitamin D. Dengan demikian dapat disimpulkan bahwa durasi paparan sinar matahari selama rata-rata 30-60 menit/ hari dapat meningkatkan kadar CD4 pada pasien HIV.

Dari literatur diketahui bahwa imunitas kulit dipengaruhi oleh paparan ultraviolet (UV) yang memengaruhi keratinosit, antigen presenting cell, seperti sel epidermal Langerhans dan limfosit T. Sel T regulator perifer responsif terhadap rangsangan lingkungan, termasuk radiasi ultraviolet. Fungsi efektor sel $\mathrm{T}$ bergantung pada status aktivasi sel Langerhans, dan sel $\mathrm{T}$ regulator yang 
diinduksi oleh UV diperluas oleh sel Langerhans kulit yang terpapar UV. ${ }^{19}$ Studi uji klinis pada populasi anak mengenai efek paparan UV terhadap kadar CD4 pasien HIV masih sangat terbatas. Adapun beberapa penelitian lain sebelumnya masih menunjukkan hasil yang kontroversial. Studi Duvic dkk ${ }^{20}$ menunjukkan bahwa setelah 6 minggu terapi UVB, rata-rata nilai CD4 pada 12 pasien yang terinfeksi HIV tidak berbeda dari nilai acuan awal. ${ }^{22}$ Studi perbandingan lain dari Fotiades $\mathrm{dkk}^{21}$ pada tahun 1995 yang melakukan fototerapi UVB pada 28 pasien HIV dengan psoriasis : (14 pasien HIV-positif, dan 14 pasien HIV-negatif). Pada kedua kelompok mengalami perbaikan klinis yang serupa. Tidak ada penurunan status imun seperti yang diukur dengan jumlah CD4 limfosit, limfosit $\mathrm{T}$ total. ${ }^{22}$ Keterbatasan dari penelitian kami adalah dilakukan pada satu pusat pengambilan sampel penelitian sehingga jumlah sampel cukup terbatas dan penelitian ini tidak dilakukan secara acak dan tersamar ganda.

\section{Kesimpulan}

Terdapat peningkatan bermakna terhadap kadar kalsidiol dan CD4 pada pasien HIV dalam terapi antiretroviral setelah terapi vitamin D.

\section{Daftar pustaka}

1. Rivera DM, Frye RE. Pediatric HIV Infection. 2018. [diakses tanggal 3 Februari 2019]. Didapat dari : https://emedicine. medscape.com/article/965086-overview.

2. Brooks M. Study supports earlier initiation of HAART in HIV infected children. Medscape Medical News. 2014.

3. Yin DE, Warshaw MG, Miller WC, dkk. Using CD4 percentage and age to optimize pediatric antiretroviral therapy initiation pediatrics. 2014;134:1104-16.

4. Welz T, Childs K, Ibrahim F, dkk. Efavirenz is associated with severe vitamin $\mathrm{D}$ deficiency and increased alkaline phosphatase. AIDS. 2010;24:1923-8.

5. Mueller NJ, Fux CA, Ledergerber B, dkk. High prevalence of severe vitamin $\mathrm{D}$ deficiency in combined antiretroviral therapy naive and successfully treated Swiss HIV patients. AIDS. 2010;24:1127-34.

6. Childs K, Welz T, Samarawickrama A, Frank A. Post. Effects of vitamin $\mathrm{D}$ deficiency and combination antiretroviral therapy on bone in HIV-positive patients. AIDS 2012;26:253-62.

7. Viard JP, Souberbielle JC, Kirk O, dkk. Vitamin D and clinical disease progression in HIV infection: results from the EuroSIDA study. AIDS 2011;25:1305-15.

8. Lee JY, So TY, Thackray J. A review on vitamin D deficiency treatment in pediatric patients. A review on vitamin D Deficiency Treatment in Pediatric Patients 2013;18:277-91.

9. Sastroasmoro S, Ismael S. Dasar-dasar metodologi penelitian klinis. Uji Klinis. Jakarta: Sagung Seto; 2014.h.196.

10. Kakalia S, Sochett EB, Stephens D, Assor E, Read SE, Bitnun A. Vitamin D supplementation and CD4 count in children infected with human immunodeficiency virus. J Pediatr 2011;159:951-7.

11. Stallings VA, Schall JI, Hediger ML, dkk. High-dose vitamin D3 supplementation in children and young adults with HIV: A randomized, placebo-controlled trial. Pediatr Infect Dis J 2015;34:32-40.

12. Zhou C, Assem M, Tay JC, dkk. Steroid and xenobiotic receptor and vitamin D receptor crosstalk mediates CYP24 expression and drug-induced osteomalacia. J Clin Invest 2006;116:1703-12.

13. Brown TT, McComsey GA. Association between initiation of antiretroviral therapy with efavirenz and decreases in 25-hydroxyvitamin D. Antivir Ther 2010;15:425-9.

14. Misra M, Pacaud D, Petryk A, Paulo Solberg FC, Kappy M. Vitamin D deficiency in children and its management: review of current knowledge and recommendations. Pediatrics 2008;122:398-417.

15. Yonemura K, Fujimoto T, Fujigaki Y, Hishida A. Vitamin $\mathrm{D}$ deficiency is implicated in reduced serum albumin concentrations in patients with end-stage renal disease. Am J Kidney Dis 2000;36:337-44.

16. Bikle DD, Siiteri PK, Ryzen E, Haddad JG. Serum protein binding of 1,25-dihydroxyvitamin $\mathrm{D}$ : A reevaluation by direct measurement of free metabolite levels. J Clin Endocrinol Metab 1985;61:969-75.

17. Coelho L, Cardoso SW, Luz PM, Hoffman RM, Mendonça L, Veloso VG. Vitamin D3 supplementation in HIV infection: effectiveness and associations with antiretroviral therapy. Nutr J 2015;14:81.

18. Loser K, Beissert S. Regulation of cutaneous immunity by the environment: an important role for UV irradiation and vitamin D. Int Immunopharmacol 2009;9:587-9.

19. Rosa MD, Malaguarnera M, Nicoletti F, Malaguarnera L. Vitamin D3: a helpful immuno-modulator. Immunology 2011;134:123-39.

20. Duvic M, Ulmer R, Crane M, Goller M, Aduppong A, Lewis DE. Treatment of HIV patients with UVB is as-sociated with a significant increase in p24 antigen levels. J Invest Dermatol 1995; 104:581A.

21. Fotiades J, Soter NA, Sanchez MR, Moy AJ. A three year follow-up evaluation on $28 \mathrm{HIV}$-positive patients treated with ultraviolet B (UVB) phototherapy. J Invest Dermatol 1995:104: 660A.

22. Akaraphanth R, Lim HW. HIV, UV and immunosuppression. Photodermatol Photoimmunol Photomed 1999;15:28-31. 